\title{
Sex still matters
}

(C) The Author(s), under exclusive licence to Springer Nature Limited 2021

Bone Marrow Transplantation (2021) 56:2622-2623; https://doi.org/ 10.1038/s41409-021-01413-8

"Wine gives courage and men more apt for passion."

Publius Ovidus Naso also known as Ovid (43 BC-17 AD). Roman Poet. Figure 1.

My first "invited editorial" for this journal, 3 years ago, was titled: "Sex matters" so, I thought I should update things.

So, let us look at donor gender and parity on the incidence of graft-versus-host disease (GvHD) in the recipient following haemopoietic cell transplantation $(\mathrm{HCT})$. It has been reported with varying degrees of agreement $[1,2]$ that there is an influence. I am never sure whether one should use the term sex or gender. Recently, a colleague from Italy, in a lecture in the Royal College of Physicians, in Dublin, discussed the influence of sex on the outcome of HCT. I interrupted from the audience and said he surely meant gender, as we have no idea (as far as I know) what the effect of sex is on the outcome of HCT!

The selection of donors for allogeneic sibling matched or unrelated HCT is extremely important, and every attempt should be made to minimize toxicity. GvHD is a major cause of morbidity and mortality following HCT so any attempt at amelioration, is to be welcomed. Specific factors influencing donor selection include, HLA matching, cytomegalovirus serologic status, ABO compatibility, age, sex/gender, and parity (i.e., the number of prior pregnancies) [3-5]. When given the option (not always available) of a sibling donor or unrelated HCT (URD) sibling donors are

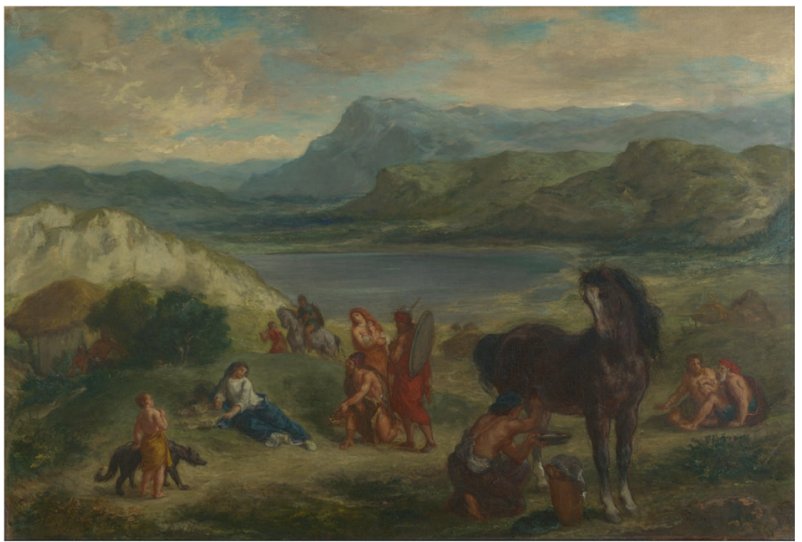

Fig. 1 Ovid (Roman poet). Ovid among the Scythians, by Eugène Delacroix. 1862, oil on wood, Metropolitan Museum of Art. Public domain. usually preferred for convenience, possibly to reduce GvHD and perhaps improve survival of the recipient.

There is an increased risk of chronic GvHD (cGvHD) and in some studies, acute GvHD, (aGvHD) in recipients of grafts from female donors, regardless of recipient sex/gender. However, some studies indicate an even greater risk in male recipients, presumably because of female donors' immune response to the $\mathrm{H}-\mathrm{Y}$ antigen. In 2006, a large registry analysis using the Center for International Blood and Marrow Transplant Research evaluated the impact of sex/gender and parity on aGvHD and CGvHD after HLA-identical sibling HCT. This study established parity as a risk factor for cGvHD in both male and female recipients from parous female sibling donors. It also demonstrated that nulliparous female sibling donors confer an increased risk of cGvHD to male recipients [6]. More recently [7], a large retrospective registry study failed to find any influence of donor gender or parity on the incidence of aGvHD or cGvHD. They concluded that "when available, parous female siblings are preferred over male URDs". So now I am totally confused.

Is there a problem in terms of sex/gender in the wine business? Most definitely yes. According to Julia Moskin writing in the NYT International October 5th 2020 in an article entitled "The wine elite's sexual harassment problem" she points out that sexual harassment is common for women who struggle to obtain the qualification of Master Sommelier (Fig. 2), the ultimate qualification for potential sommeliers. In some instances, sexual harassment is so blatant that it forces women to retire from the business. Three men have apparently been suspended and one has

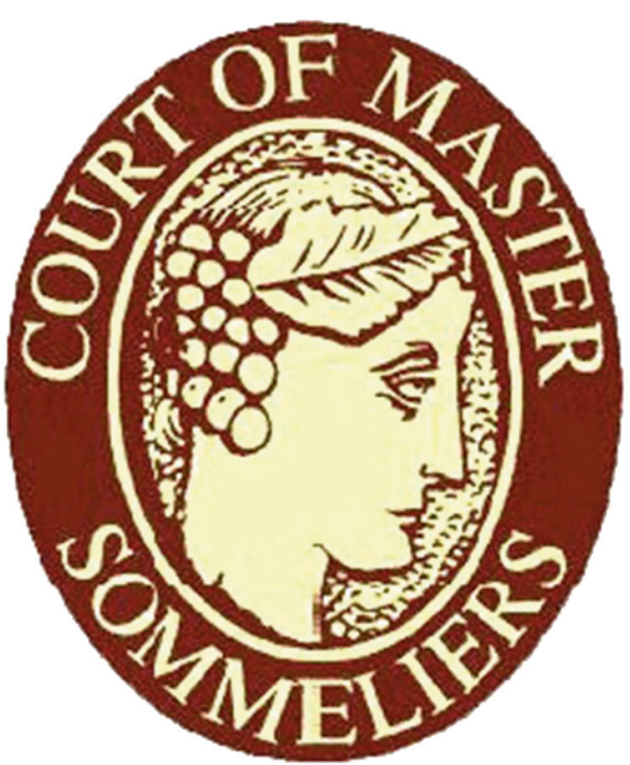

Fig. 2 Court of Grand Masters emblem. Master Sommelier Pin. The symbol of the Court of Master Sommeliers in the USA. 


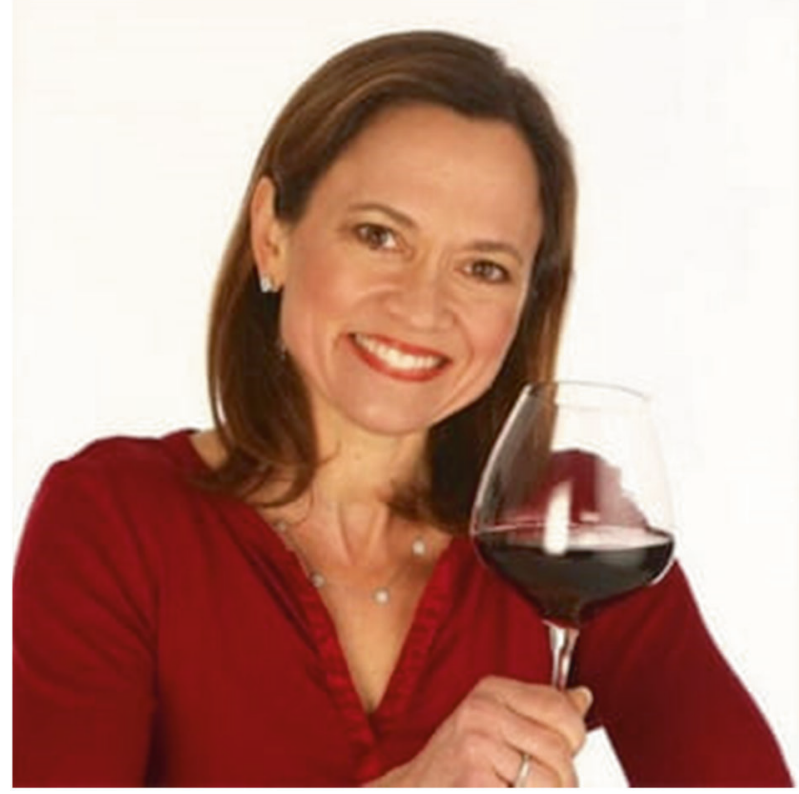

Fig. 3 Robinson A. Master sommelier. Blog. 2021. Beverage Trade Network, Wilmington, Delaware, USA.

resigned from the Court of Master Sommeliers, the examining body that confers the title of Master Sommelier. The Chairman at the Court of Master Sommeliers-Americas stepped down on November 6th 2020.

I previously pointed out the rise of women sommeliers [8], however, if Ms Moskin is to be believed, and I am sure she is, misogyny and sexism are still rife in the wine business as in many other professions. I think it is fair to say that medicine is not rife with misogyny although there are few women orthopedic surgeons but that may be for other reasons. Why should this be? Needless to say, the majority of Master Sommeliers are men $(131 / 155)$ and they earn high salaries and doubtless enjoy many perks (other than sexual). Keeping women out of exalted positions increases the likelihood of men obtaining these coveted positions. However, Pascaline Lepeltier, laureate of "Un des Meilleurs Ouvriers de France-Sommellierie," was crowned Best French Sommelier in 2018. Could it be that Sigmund Freud's "castration complex" exists after all, or is it just a matter of money?

Sommelier Amber Gardner, writing in her opinion blog on October 12th 2020 wrote: "...Yet I realize that I am not, and never will be, part of the inner club of wine-the boy's club-that still dominated the wine industry". Jancis Robinson in the FT magazine wrote, about a wine tasting in the mid-1980s, when she was asked the question: "I say, do you come to these things to taste for your boss"? [9]. Whatever the reason, it is clearly unacceptable. Surely it is the quality of the wine, which in the end is decided by the wine drinker, not the gender of the person recommending a particular bottle (Fig. 3), that is of paramount importance.?

As I have said before, my wife is a better wine taster than me and I usually defer to her. Remember, wine drinking should be an enjoyable experience and not one associated with stress or any unpleasant emotion. For those involved in HCT, wine consumption should be a release valve from a stressful occupation. As Oscar Wilde, Irish playwright said: "I drink to separate my body from my soul".

\section{Shaun R. McCann (D) $^{1 凶}$ \\ ${ }^{1}$ Department of Haematology, Trinity College, Dublin, Ireland. 凶email: shaunrmccann@gmail.com}

\section{REFERENCES}

1. Kim HT, Zhang M-J, Woolfrey AE, St Martin A, Chen J, Saber W, et al. Donor and recipient sex in allogeneic stem cell transplantation: what really matters. Haematologica. 2016;101:1260-6.

2. Flowers ME, Pepe MS, Longton G, Doney KC, Monroe D, Witherspoon RP, et al. Previous donor pregnancy as a risk factor for acute graft-versus-host disease in patients with aplastic anaemia treated by allogeneic marrow transplantation. $\mathrm{Br} \mathrm{J}$ Haematol. 1990;74:492-6.

3. Kanda J, Ichinohe T, Matsuo K, Benjamin RJ, KlumppT R, Rozman P, et al. Impact of $\mathrm{ABO}$ mismatching on the outcomes of allogeneic related and unrelated blood and marrow stem cell transplantations for hematologic malignancies: IPD-based metaanalysis of cohort studies. Transfusion. 2009;49:624-35.

4. Kollman C, Spellman SR, Zhang MJ, Hassebroek A, Anasetti C, Antin JH, et al. The effect of donor characteristics on survival after unrelated donor transplantation for hematologic malignancy. Blood. 2016;127:260-7.

5. Schmidt-Hieber M, Labopin M, Beelen D, Volin L, Ehninger G, Finke J, et al. CMV serostatus still has an important prognostic impact in de novo acute leukemia patients after allogeneic stem cell transplantation: a report from the Acute Leukemia Working Party of EBMT. Blood. 2013;122:3359-64.

6. Loren AW, Bunin GR, Boudreau C, Champlin RE, Avitol C, Horowitz MM, et al. Impact of donor and recipient sex and parity on outcomes of HLA-identical sibling allogeneic hematopoietic stem cell transplantation. Biol Blood Marrow Transpl. 2006;12:758-69.

7. Kumar AJ, Kim S, Hemmer MT, Arora M, Spellman SR, Pidala JA, et al. Graft-versushost disease in recipients of male unrelated donor compared with parous female sibling donor transplants. Blood Adv. 2018. https://doi.org/10.1182/ bloodadvances.2017013052.

8. McCann SR. Sex matters. Bone Marrow Transpl. 2018. https://doi.org/10.1038/ s41409-018-0186-5.

9. Robinson J. Women and wine: a tipping point. FT.com/magazine. London, UK: Financial Times Ltd; 2020.

\section{AUTHOR CONTRIBUTIONS}

I am the sole author.

\section{COMPETING INTERESTS}

The author declares no competing interests.

\section{ADDITIONAL INFORMATION}

Correspondence and requests for materials should be addressed to S.R.M.

Reprints and permission information is available at http://www.nature.com/ reprints

Publisher's note Springer Nature remains neutral with regard to jurisdictional claims in published maps and institutional affiliations. 